\title{
Motivations for Indigenous island entrepreneurship: Entrepreneurs and behavioral economics in Greenland
}

\author{
Christian William Wennecke \\ Independent researcher, Greenland \\ christian@innovation.gl (corresponding author)
}

\author{
Rikke Becker Jacobsen \\ Innovative Fisheries Management, Aalborg University, Denmark \\ rbj@ifm.aau.dk
}

Carina Ren

Department of Culture and Learning, Aalborg University, Denmark ren@cgs.aau.dk

\begin{abstract}
Greenland continues to undergo decolonization, the ultimate political ambition being a 'self-sustaining economy' and political independence from Denmark. Drawing on a recent survey in combination with ethnographic fieldwork, this paper explores the connection between political independence and entrepreneurial activities in Greenland. While entrepreneurs are increasingly expected to play a central role in fostering economic change, we are curious about what motivates them, and especially whether their motivations are related to the struggle for national independence. While entrepreneurship generally seems primarily motivated by a desire for personal autonomy, entrepreneurship in the context of an Indigenous island community seems driven by certain communal values, such as supporting the local community, cultural pride, family, and place. Our research supports the notion that entrepreneurship is motivated by non-pecuniary values, and we find entrepreneurship to result from a mesh of intertwined motivations. While we were unable to identify a direct link between the ambition for national autonomy and entrepreneurship, the paper contributes to the understanding of entrepreneurship as an instrument for decolonization drawing on a range of empirical cases and a multi-disciplinary approach.
\end{abstract}

Keywords: behavioral economics, entrepreneurship, Greenland, Indigenous, Indigenous island entrepreneurship, islands

https://doi.org/10.24043/isj.99 • Received February 2019, accepted August 2019

(C) 2019-Institute of Island Studies, University of Prince Edward Island, Canada. 


\section{Introduction}

This study explores the links between entrepreneurship and decolonization in Greenland. Entrepreneurship is widely recognized as the driving force behind economic development, which itself is a prerequisite for political independence in the form of a 'self-sustaining economy'.

It is documented by Gustav Agneman (2019), that the majority (55\%) of the Greenlandic population finds the question of political independence important, and about half of them find it 'extremely important'. And those who find it important tend to be in favor of independence. According to this study, there will be a majority for independence between 2030 and 2035 depending on the population's level of information about the economic consequences. It is generally accepted that economic change has its roots in entrepreneurship, and since the issue of having a self-sustaining economy is at the heart of the discussion of independence, entrepreneurs seem to be needed to advance the political ambition for national autonomy.

According to theories of Indigenous entrepreneurship and behavioral economics, entrepreneurship in small communities largely results from non-pecuniary motives. Entrepreneurship is rarely driven by dreams of wealth in such communities. Instead of individual utility, entrepreneurship in these communities would largely appear motivated by community or even national values. To explore this in further depth in Greenland, we pursue a dual research question: 1) What motivates entrepreneurship? 2) How important is the ambition for national autonomy in motivating entrepreneurship?

After introducing our methodology and our theoretical approach to entrepreneurship, we present our empirical material, which is drawn from surveys, interviews, and observations. We then proceed to the analytical section, where we explore motivations for entrepreneurship in Greenland in further depth. We discuss how our case contributes to the understanding of entrepreneurship beyond standard economic rationality. We argue that multiple and interrelated motivations-across the personal, local, and national levels-inspire entrepreneurial activities in a meaningful way. To illustrate our inquiry, we commence with a short example of a local brewery in South Greenland, which directly embraces the quest for independence in its branding.

\section{Beer 'for independent Greenlanders'}

Qajaq Brewery was established in 2015 by the owners of Hotel Narsaq in South Greenland. According to the two entrepreneurs - a Greenlandic woman and her Icelandic husbandthey were shocked to learn that $99 \%$ of all beer sold in Greenland was produced in Denmark, and their brewery operations were motivated by a desire for Greenlandic self-sufficiency.

Owner Fridrik Magnusson explains the thoughts behind 'Greenlandic beer for the Greenlanders' in a 2016 interview for a travel blog, An Adventurous World: "We want our beer to create a strong Greenlandic symbol to unify and educate people. I believe it can be done and hopefully put one tiny foundation towards a revolution against foreigners" (qtd. in Sherifi, 2016).

By 'foreigners', Magnusson is probably referring to the dominant Danish beers from Carlsberg and Royal Unibrew, and it is a point worth noting that the replacement of imports with local production lies at the heart of the entrepreneurial take on establishing an 
economically independent Greenland. This is reinforced by the text on the Qajaq labels, such as: "Qajaq Beer is locally produced which eliminates the import of outside corporate products that drain the islands [sic] domestic economy" (see Figure 1).

Some of the Qajaq beers have labels stating 'For independent Greenlanders', written in English, together with a message in Greenlandic. These messages include: 'Piffisaq nallerpoq- Sapinngilagut' ('The time has come-We can do it') and 'Uagulli Nammineq' ('How about doing it ourselves?'). This example illustrates how some Greenlandic entrepreneurs see their entrepreneurship as an enabling factor for creating an economy that is less dependent on outside industry and imports.

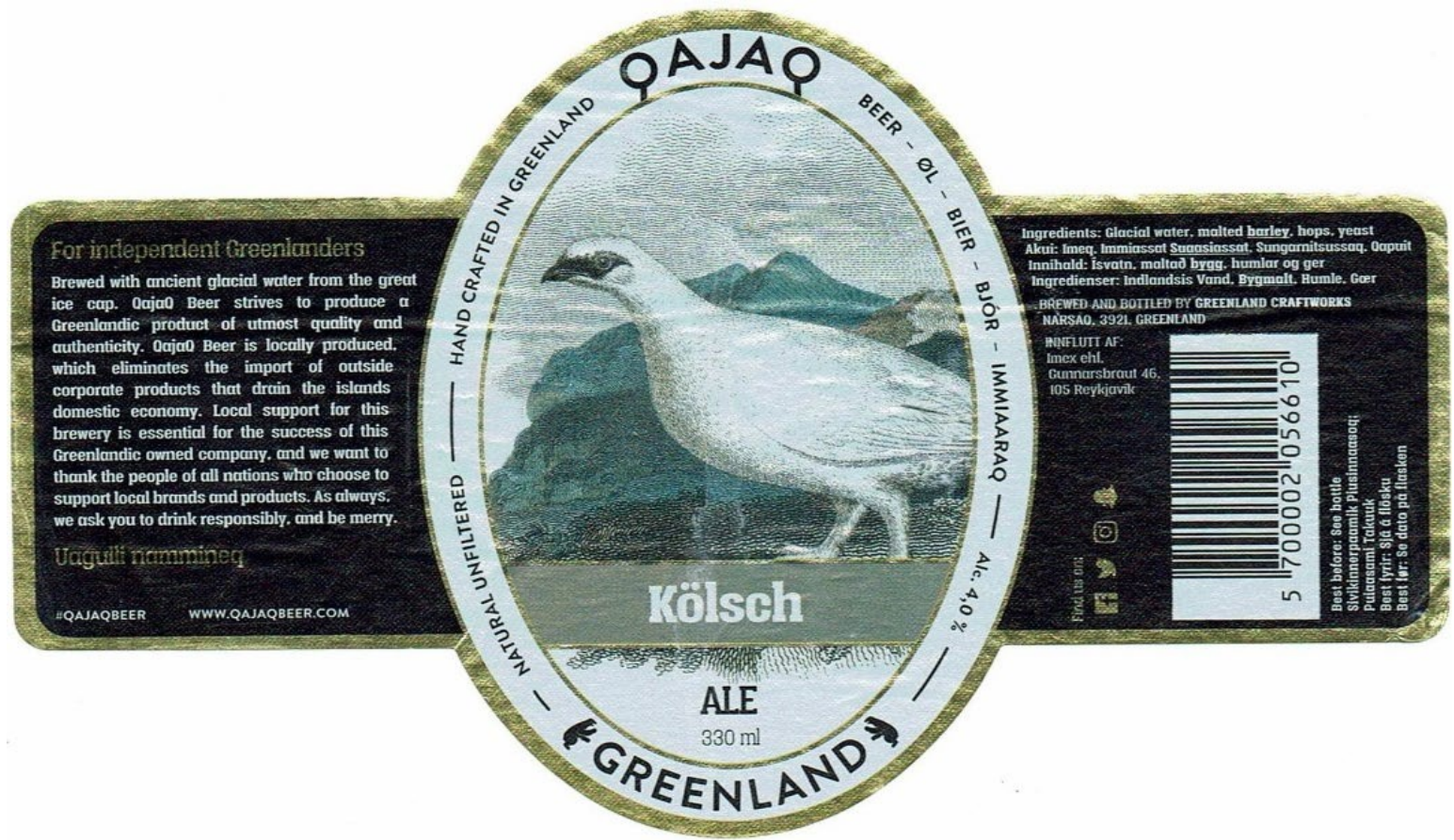

Figure 1: Label from Qajaq Brewery. Photo: Kay-Verner Christiansen.

\section{Greenland in context}

While Greenland is often referred to as the largest island in the world, it might be more meaningful to view it as a dispersed archipelago. There is on average $235 \mathrm{~km}$ (as the crow flies) unroaded, mountainous terrain between towns, and Greenland is the most sparsely populated country or dependent territory in the world (CIA, 2018). Greenland is home to 55,992 people, $10 \%$ of whom were born elsewhere. The population has been declining for more than a decade and is predicted to fall by a further 3,000 people by 2040 (Grønlands Statistik, 2019).

Fisheries account for $92 \%$ of Greenland's exports. Due to the very limited production of commodities, almost all goods consumed by households and companies are imported. While this results in a trade deficit, the balance of payment is kept positive for Greenland by a relatively large annual block grant received from Denmark. 


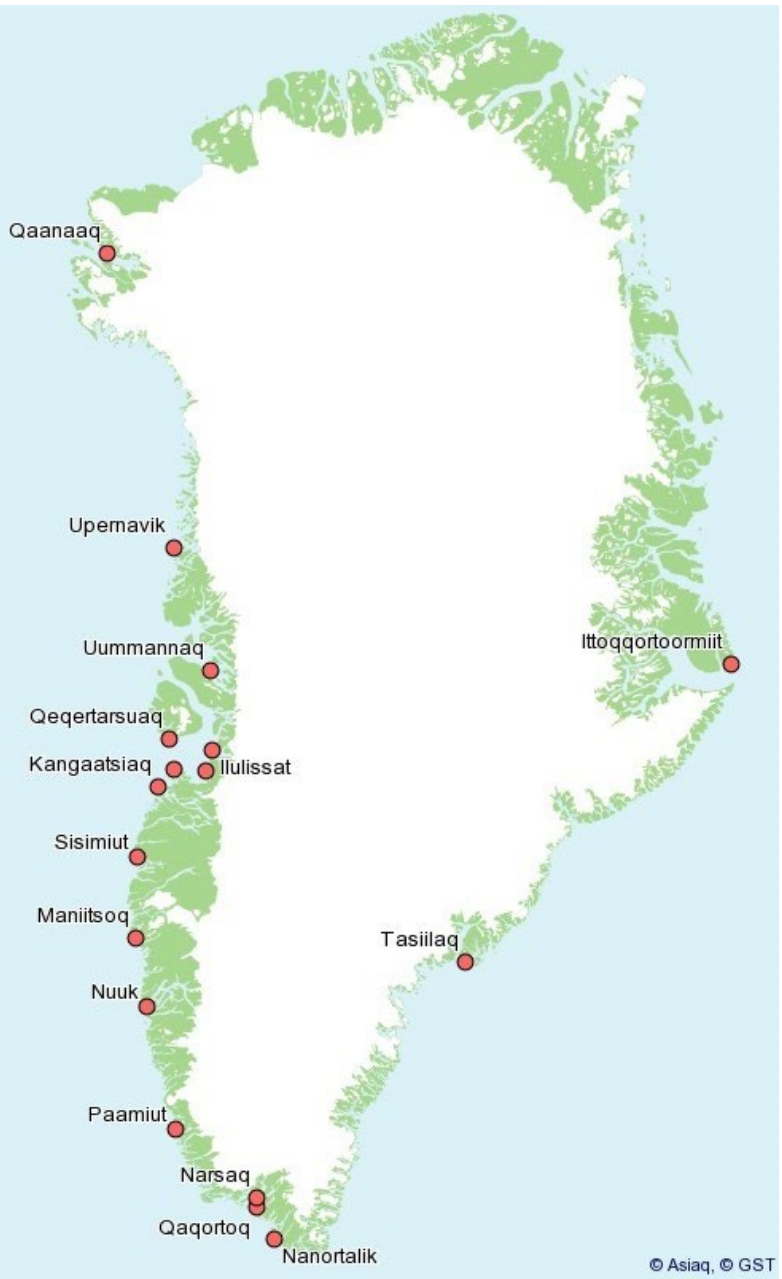

Figure 2: An archipelago of towns. Source: (C) Asiaq.

\section{Self-sustaining economy}

As used in Greenlandic politics, the concept of being 'self-sustaining' (imminut napatittoq in Greenlandic or selvboerende in Danish) places emphasis on independence, on Greenland sustaining its 'self'. The concept of the 'self-sustaining economy' is used by the Greenlandic Administration as the overarching goal of preparing the national economy for independence (Departement for Finanser, 2016). In its 2018 Economic Report, the Government of Greenland (Departement for Finanser, 2018, p.31) has suggested an indicator for selfsustainable economy as "The relative size of the block grant compared to GDP." Together with 13 other indicators, it is meant to be used to evaluate progress towards the goals forwarded in the government plan for sustainability and growth (Departement for Finanser, 2016) to ensure solid public finances, with four reform tracks:

- Modernization of the public sector

- Promotion of growth and creating a more diverse economy

- Increased education levels

- Increased self-reliance through the reform of welfare benefits, taxes, and residential policy. 
According to Wennecke (2017), the 'self-sustaining economy' concept requires an aspect of sustainability as well as independence, which for Greenland comes down to 1) termination of the block grant (independence), 2) devolution of all political powers (independence), 3) solid public finances (sustainability), and 4) living standards comparable to those of Denmark (sustainability).

With this interpretation of 'self-sustaining economy', there is an even greater need for economic development in Greenland than simply reducing the size of the block grant in relation to GDP. The Act on Greenland Self-Government includes provisions on how to regulate the annual block grant from Denmark to Greenland. According to this law, the block grant should be reduced by half of all mineral resource revenues exceeding 75 million Danish kroner (approximately $€ 10$ million). Relying solely on mineral resources for phasing out the block grant was not considered a possibility while maintaining the Indigenous population as the majority of the population; not for at least 20-50 years, as assessed by the Committee for Greenlandic Mineral Resources to the Benefit of Society (Rosing, Knudsen, Heinrich, \& Rasmussen, 2014). Instead, economic development should be diverse and requires the establishment of new businesses in Greenland within many sectors, which underscores how Greenland needs innovation and entrepreneurs in order to achieve independence.

\section{A theory for entrepreneurship in Indigenous island communities}

Entrepreneurship is increasingly recognized as an important factor for economic development. Schumpeter (1942) was the first to point out the role of the entrepreneur in economic development, perceiving entrepreneurial innovations as a key driver in what he calls 'creative destruction'-explaining how new innovations render old solutions obsolete. Grigore et al (2014) contend that entrepreneurs influence economic development, as they reallocate resources to more productive uses, creating jobs and innovation, which leads to new products and welfare services.

While entrepreneurship can be viewed as a driver for economic development, another growing body of literature suggests that the very behavior of entrepreneurs cannot be fully understood in terms of economic rationality nor the systemic logic of capitalism. An important insight from behavioral economics holds that due to limitations of time and cognitive capacity, individuals' decisions are made under 'bounded rationality'. According to Kahneman (2011), the mind operates in two systems, one that operates quickly, effortlessly, and rather unconsciously, and another that handles effortful mental activities, complex computations, and conscious deliberation. Studies have shown that even apparently rational thinking is constantly influenced by the shortcuts induced by the first system, which promotes irrational behavior, such as overconfidence (Kahneman, 2011).

Åstebro et al (2014) identify three types of overconfidence among entrepreneurs. The average entrepreneur generally views their abilities higher than they are, higher than those of others, and thinks they know the market better than they really do. This may account for why there is too much entry into entrepreneurship, but it does not explain the mounting evidence of persistence in entrepreneurship despite the low average returns. Instead, Åstebro et al (2014) find evidence that nonpecuniary benefits play an important role in the decision to become an entrepreneur and remain in entrepreneurship more often than the entrepreneur should have if they acted according to standard economic rationality. But they also point out 
that no one behavioral interpretation can be identified as the primary factor. More research is needed to develop a better understanding of how behavioral interpretations affect the decisions of entrepreneurs in different circumstances and to disentangle the many different factors.

Steenholdt and Chimirri (2018) have studied the relationship between tourism entrepreneurship and quality of life in South Greenland. Their main findings are that tourism entrepreneurship provides the opportunity for a self-sustaining lifestyle and that it corresponds with the entrepreneur's need for cultural vitality, control over their own fate, and contact with nature. The social indicators mentioned here were developed in a 2010 report on Arctic social indicators, seeking to fill the gap left by the more mainstream socio-economic indicators found in the Human Development Index (GDP per capita, education, and health). This gives a broader perspective on tourism entrepreneurship among farmers in South Greenland, which clearly has other purposes than being the best income opportunity.

Dana (2007, 2015), Gallagher (2015), and Mika et al (2017) identify 'Indigenous entrepreneurship' as an emerging field of research. This field explores the interactions between Indigenous identities and entrepreneurship, arguing that Indigenous identities can influence and impact entrepreneurship and vice versa. Based on empirical case studies worldwide, this literature finds evidence that Indigenous groups and individuals make use of their indigeneity as a source of inspiration and innovation in entrepreneurship. The literature argues and showcases how Indigenous entrepreneurship must be understood and explained with reference to a context that is specific to the individual Indigenous group. Relevant contexts often include different colonial histories, contemporary governance, devolution arrangements, and peripheral location (Mika et al, 2017).

In Arctic Canada, Dana (2007, 2015) has emphasized Inuit hunting activities in his understanding of Indigenous Inuit entrepreneurship and presented the argument that Indigenous entrepreneurs in Canada did not consider options of entrepreneurship in other parts of the economy. Here, egalitarianism, sharing, communal activity, and kinship ties shape entrepreneurship more than do market relations. A perspective on the contemporary case of 'Indigenous' entrepreneurship in Greenland is interesting, because the context for Indigenous economic participation and self-governance is different from those of many other Indigenous populations in Arctic and around the world. We argue that the context in Greenland is not just one of Inuit indigeneity and the marginalization of a minority within the Kingdom of Denmark; it is also one of Greenlandic nation-building of a majority population within an emerging nation-state structure. Furthermore, Greenlandic entrepreneurs also participate actively in many different parts of the Greenlandic economy. Some of the newest research from Greenland shows that the consumption of Inuit entrepreneur products (e.g. fashion design) is also produced and consumed within the context of nation-building and contested identities (Rossen, 2018, 2019).

A growing literature on island and rural entrepreneurship has revealed how remote, place-bound identities and assets are increasingly being put to use, negotiated, and promoted in entrepreneurship around the world (Baldacchino, 2015; Burnett \& Danson 2017). This tendency is explained within the context of globalization and uneven economic development, where 'left-out' communities can now make positive use of their peripherality in an experience-based economy. Greenlandic entrepreneurship by Greenlandic Inuit also speaks to this discussion. The question of settlement, demography, and livelihood outside the major urban areas is an important political discussion in Greenland. Greenlandic towns and 
municipalities struggle with declining populations and a sense of decline as an almost direct effect of closed fishing plants and lost fishing opportunities. Indeed, this article partly emerged from a regionally motivated research project exploring the potential connections between sustainability, small-scale businesses, and demographic development in one such region: South Greenland.

The barriers and challenges for entrepreneurship in rural, remote, or island locations are often identified in terms of less market access, complicated infrastructure, and declining populations. This also applies to the analysis of entrepreneurship in Greenland (Sejersen, 2007). However, most of the literature on rural entrepreneurship actually offers examples of resourceful entrepreneurship in remote locations. Across the globe, entrepreneurship has succeeded and provided welfare and employment (Labriandis, 2006; Pato \& Teixeira, 2014). It has reinvigorated communities in demographic and economic decline. Entrepreneurship has even been described as an 'entrepreneurial energy' that runs through a community (Gaddefors \& Anderson, 2018). Emerging literature even argues that island and microstate entrepreneurs are successful not in spite of but rather because of their political and geographical locations. Their unique location and context offer place-based resources, together with a range of beneficial special arrangements in the geopolitical landscape (Baldacchino, 2015).

This article proposes understanding Greenland entrepreneurship in terms of Indigenous entrepreneurship, entrepreneurship taking place on islands and in remote places, and entrepreneurship promoted by an island state that continues to aspire to independence and a self-sustaining economy. Our study adds to the existing theory on entrepreneurship in context by exploring the extent to which entrepreneurship in remote, Indigenous, and island communities is entangled with the context of political island ambitions of decolonialization and nation-building in the concrete form of a 'self-sustaining' national economy. We do so by carefully exploring entrepreneurs' motivations and valuations of their own entrepreneurship in Greenland.

\section{Methodology: pragmatism, mixed methods, and positionality}

In an article entitled 'Expanding the scope of methodologies used in entrepreneurship research', Dana and Dana (2005, p.80) argue for the need to challenge dominant hypotheticodeductive research within entrepreneurship research in order to gain a more holistic understanding. They see the role of culture as central to grasping entrepreneurial motivation and therefore suggest a qualitative, case-based approach. Our methodology is inspired by this and similar approaches that acknowledge - as argued above- the role of context in how we make sense of, organize, and live in the world.

However, our research ambitions also reflect a pragmatic interest in operationalizing insights from fieldwork and in-depth interviews in contemporary policy work in Greenland and, thus, as argued by Flyvbjerg (2001), in making social science matter. This is reflected in our methodology, which takes an abductive, mixed methods approach, described in greater detail below, in which insights from fieldwork and interviews are used to inform the crafting of the survey and, again, after the survey was conducted, to supplement its numerical outcomes with quotes and to revisit and inquire back into our qualitative material.

By working to "bring the numbers and stories together" (Ren \& Mahadevan, 2018), we aspire to produce robust, value-driven knowledge. As argued by Gupta and Ferguson 
(1997), we see our task as researchers "not as 'sharing' knowledges with those who lack it, but as forging links between different knowledges that are possible from different locations and tracing lines of possible alliance and common purpose between them" (Gupta \& Ferguson, 1997, p.39). This quote indicates how research is never 'innocent' and underlines the necessity of making research positionality transparent.

The first author in our team is positioned within Greenland Business, which is partly owned by the Self-Government of Greenland. The other authors are researchers employed by a Danish university. While none of the authors are Inuit, we all have a strong affiliation to Greenlandic society resulting from long-term residence, work experience, personal, and/or family relations. None of the researchers hold strong opinions regarding the independence question per se, but all are interested in how Greenland and its inhabitants can obtain sustainable livelihoods and economies. While this contrasted with the strong opinions for or against Danish influence and dependence held by some interviewees, we have deliberatively sought to understand and communicate all the motivations and impacts of Indigenous entrepreneurs in rural communities using a mixed methods approach.

\section{A mixed methods approach}

The material used in our analysis draws upon several different sources, the first stemming from ethnographic fieldwork on small-scale businesses and sustainable demography conducted in South Greenland in the winter of 2018. The fieldwork included 12 qualitative interviews conducted with a total of 19 people from Qaqortoq, Narsaq, and Narsarsuaq. Interviewees include small business owners and entrepreneurs within tourism, farming, and fisheries; teachers and students in food and tourism-related education programs; and Greenlandic and international tourist guides.

A second source from which we draw is a round of interviews conducted in 2016-2017 in relation to a study mapping the Greenland tourism landscape (Ren \& Chimirri, 2017). The interviews with tourism actors in Greenland, 23 in total, did not specifically focus on entrepreneurship. However, as we identified interesting issues related to our current discussion in the material, the transcribed interviews were revisited with entrepreneurship in mind.

The last data source is an entrepreneurship survey carried out by Greenland Business (2019) in 2018. The survey was sent to numerous commercial enterprises within 'land-based industry' (excluding fisheries, farming, and mining) registered in Greenland. 632 people accepted the survey, and the response rate was 16\%, with 99 respondents. The 2018 entrepreneurship survey asked the entrepreneurs closed questions about the status of their business, their views on the future, their knowledge of government support programs, and their motivation for and perceived obstacles to entrepreneurship.

The Greenland Business entrepreneur survey was constructed on the basis of a literature review of 51 selected studies on entrepreneurship from the period 2008-2013. It operates with a "multi-dimensional typology of entrepreneurial motivation" containing seven dimensions, some of which are included more often in entrepreneurial surveys than others (Drews et al, 2015). The survey questions were co-developed by Greenland Business and the authors of the present study. Based on the insights that had already been generated in the interviews mentioned above, a set of 11 motivational factors was identified. In Table 1 below, we describe the identified dimensions and how they connect to the questions in the Greenland 
Business Entrepreneur survey. Roughly half of the questions concern standard economic rational motivations, and the other half concern social motivations at various scales.

Table 1: Dimensions in the motivation to become an entrepreneur.

\begin{tabular}{|c|c|c|c|}
\hline & $\begin{array}{l}\text { Dimensions in } \\
\text { literature }\end{array}$ & Explanation & $\begin{array}{l}13 \text { survey questions (How } \\
\text { important is this } \\
\text { motivation for becoming } \\
\text { an entrepreneur/self- } \\
\text { employed?) }\end{array}$ \\
\hline \multirow{4}{*}{ 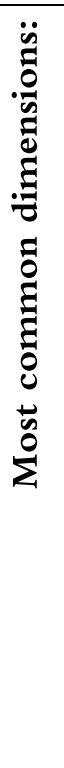 } & $\begin{array}{l}\text { Achievement, } \\
\text { challenge, and } \\
\text { learning }\end{array}$ & $\begin{array}{l}\text { Desire for personal development } \\
\text { through entrepreneurship, } \\
\text { including having the perfect job }\end{array}$ & - Create new products \\
\hline & $\begin{array}{l}\text { Independence and } \\
\text { autonomy }\end{array}$ & $\begin{array}{l}\text { Control over one's work life, } \\
\text { independent decision-making, and } \\
\text { flexibility }\end{array}$ & $\begin{array}{l}\text { - Opportunity to make my } \\
\text { own decisions }\end{array}$ \\
\hline & $\begin{array}{l}\text { Income security and } \\
\text { financial success }\end{array}$ & Importance of financial return & $\begin{array}{l}\text { - Earn more than from wage } \\
\text { labor } \\
\text { - A large successful } \\
\text { company }\end{array}$ \\
\hline & $\begin{array}{l}\text { Recognition and } \\
\text { status }\end{array}$ & $\begin{array}{l}\text { Social status of entrepreneurship, } \\
\text { recognition, and respect from } \\
\text { family/friends/community }\end{array}$ & - Recognition by others \\
\hline \multirow{3}{*}{ 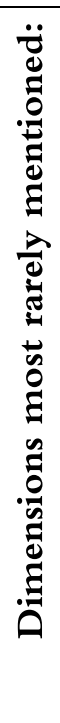 } & Dissatisfaction & $\begin{array}{l}\text { Dissatisfaction with prior work } \\
\text { arrangement }\end{array}$ & (not included) \\
\hline & Family and roles & $\begin{array}{l}\text { Desire to continue a family } \\
\text { tradition or create a family legacy }\end{array}$ & $\begin{array}{l}\text { - Live close to relatives and } \\
\text { friends } \\
\text { - Pass on specific values to my } \\
\text { children } \\
\text { - Stay where I am living }\end{array}$ \\
\hline & $\begin{array}{l}\text { Community and } \\
\text { social motivations }\end{array}$ & $\begin{array}{l}\text { Desire to give back to the } \\
\text { community, including being } \\
\text { environmentally friendly and } \\
\text { looking after one's employees }\end{array}$ & $\begin{array}{l}\text { - A factor for an independent } \\
\text { Greenland } \\
\text { - Promoting Greenlandic } \\
\text { products through exports } \\
\text { - Create development in my } \\
\text { hometown }\end{array}$ \\
\hline
\end{tabular}

For each question, the respondent was asked to state the importance on a 5-point scale spanning from very important to very unimportant, including a neutral position in the middle.

In developing our analysis, presented below, recurrent patterns and themes were searched for and identified in the survey and interview material. While the survey data is used to illuminate general patterns in entrepreneurs' motivations, interview extracts were used to illustrate and elaborate upon selected aspects of the entrepreneurial activities. 
In the analysis that follows, we explore four dimensions of entrepreneurial motivations among Greenlandic entrepreneurs that emerged from our data: personal and national autonomy, supporting local community, cultural and personal pride, and family life and staying in a place.

\section{Understanding motivations in Greenlandic Indigenous entrepreneurship}

Personal and national autonomy

In 'Entrepreneur Survey 2018', Greenland Business (2019) asked entrepreneurs to indicate the importance of 11 different sources of motivation, as explained in the methodology section.

\section{Motivation to become an entrepreneur}

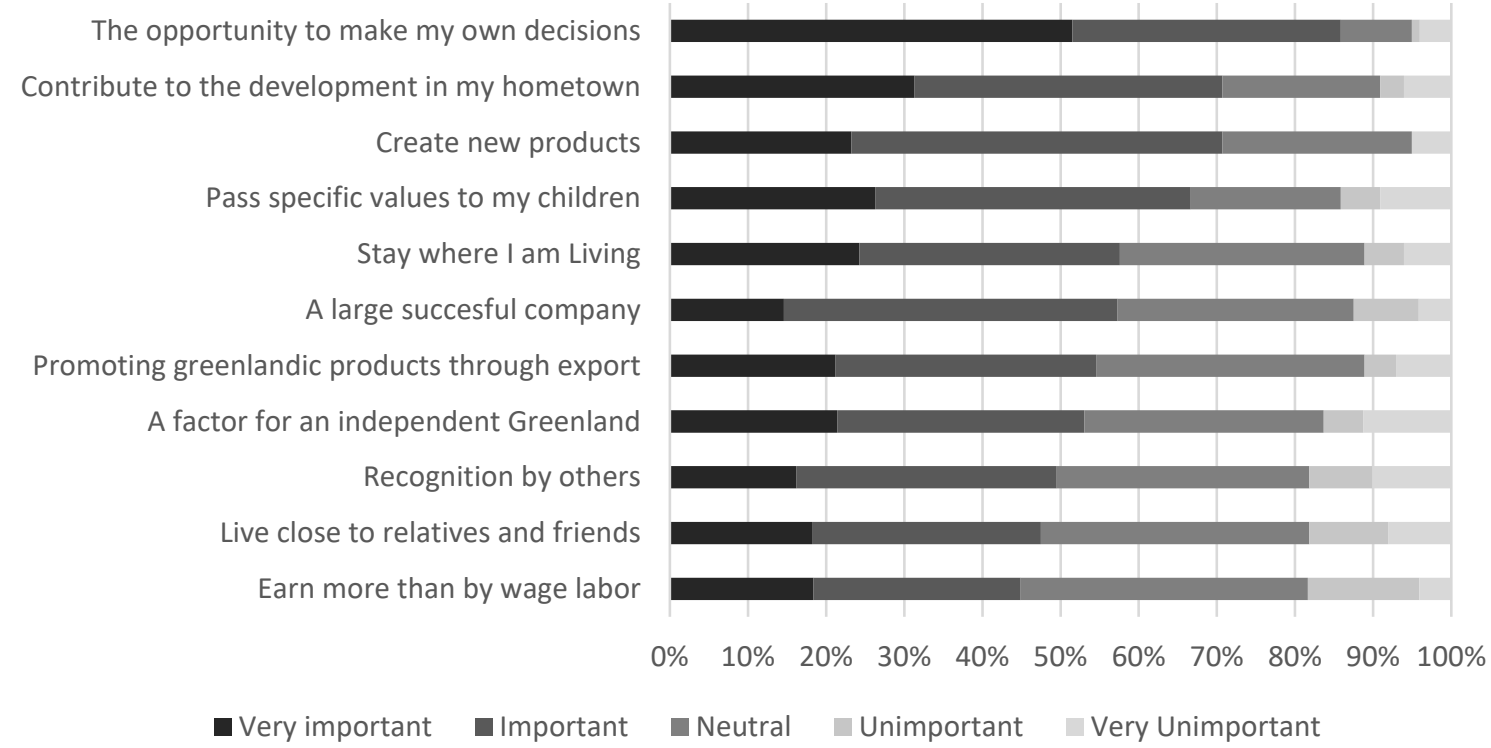

Figure 3: Motivation to become an entrepreneur. Source: Greenland Business (2019).

The survey data shows that the most common motivation among Greenlandic entrepreneurs is 'the opportunity to make my own decisions', which was important or very important for $85 \%$ of respondents. On the other end of the scale is the motivation to earn more than from wage labor. Consistent with the behavioral approach to entrepreneurship, many entrepreneurs are not motivated by the prospect of earning an above-average salary; rather, as other studies suggest, entrepreneurs appear willing to surrender wealth in order to maintain control (Åstebro et al, 2014). The high ranking of the personal autonomy motivation is also in line with this.

$52 \%$ of the entrepreneurs are motivated by being a factor for an independent Greenland. In this respect, entrepreneurs mirror the Greenlandic population at large. The ambitions for national autonomy are great and widespread in Greenland, although the question seems to split the population. If there was a referendum today, $37 \%$ of the population would vote for independence; however, 67\% "think that Greenland should become an independent country at some point in the future" (Agneman, 2019, p.48). 
National autonomy is a motivation to most Greenlandic entrepreneurs. However, this motivation ranks relatively low compared to other motivations. So, the question of national autonomy seems to be central to life in Greenland in general, rather than central to the decision to become an entrepreneur.

\section{Supporting local communities through entrepreneurship}

According to the survey (Figure 3), the second most important motivation is 'contribute to the development in my hometown'. Our interview data suggests that entrepreneurs are motivated by developing local communities among a number of intertwined motivations.

I've lived 10 years [abroad...] Then we had some children and felt we wanted them to learn Greenlandic, so we moved back [to my hometown]. The idea was for us to be here for two years and then move back. But we stayed longer and have now been here for four years [...] But our plan is to move back to [that country] at some point. But of course, we would like to give some more life to our town, so people have places to work and such things. (Entrepreneur)

In the case of this couple, multiple motivations-family life, supporting the hometown, passing on Greenlandic values (language), and innovative product development - all appear to be at stake simultaneously.

Another entrepreneur interprets the need for entrepreneurship in a context of unemployment and economic recession as she elaborates upon the need to resurrect a broader sense of pride and meaning among people by creating new economic development in the region and in Greenland in general. Economic independence, pride, and an entrepreneurial mindset are indirectly interlinked in this understanding of the entrepreneurs' motivation visà-vis society:

I'm a very independent woman. I have that from my mother-she raised seven children [...] We never ask the municipality or anyone else for help, that's her pride. She will manage, and I have that, and I want to expand that. [...] Everyone worked when I was a child, it was shift work [...] Suddenly they closed the fish plant and moved it [...] It doesn't have to be the mayor bringing business opportunities because there are tourists who want to come. We live off cruise tourism [...] If we don't start, they will never come, so I started small. (Entrepreneur)

In a recent report mapping the Greenlandic tourism sector (Ren \& Chimirri, 2017, p.20), Greenlandic tourism actors point to an increased interest in entrepreneurship 'from below' in the wake of slowly growing tourism intensification. In the words of one tourism entrepreneur, "Especially in tourism now, you can see a potential. It's really moving forward. And people see that potential and start new things towards exploiting it." While tourism numbers in Greenland remain relatively modest, recent reports and strategies point to the potential development of this industry as a positive contribution to a self-sustaining economy (Rambøll, 2014; Bjørst \& Ren, 2015). 
Tourism entrepreneurs in Greenland are typically small, often seasonal initiatives, offering services or products such as equipment, souvenirs, food, or excursions. This is no different from other businesses, and according to the Greenland Business Entrepreneur survey, only $16 \%$ of the responding businesses hire more than two people. The businesses are often characterized by collaboration, which, as stated by a tourism actor in West Greenland, creates benefits beyond the businesses themselves: "When you have small entrepreneurs in a small community, everyone relies on the others, and we all get a little share of the cake."

Tourism actors identify entrepreneurship in tourism as a potential lever for lifting Greenlandic businesses and communities. As stated by a tourism actor in Greenland, "We see more and more people getting into the tourism business, taking the guide education, and we hear about people who are thinking of starting something new in Greenland, which is very positive." The tourism product often consists of many different 'subservices', such as transportation, accommodation, and catering, to mention the most basic. In order to create and deliver tourism products, tourism actors therefore rely on each other and need to work together. An example of how entrepreneurial activities and collaboration emerge on a community scale comes from cruise tourism, where smaller villages in northern Greenland often involve the entire village. According to a cruise operator:

When the cruise ships come in, the locals are all in their national costumes, and everybody is selling small things, souvenirs. This is what they're doing now. That's what is needed. It's not one or two operators in a small town-it needs to be the whole community. (Cruise operator)

Qaqortoq in South Greenland is the largest cruise tourism port in Greenland, and the town has already become actively involved in this tourism with multiple small-scale activities, including the sale of handicrafts and the kaffemik (cake and coffee) cultural experience. Local guides show tourists around town on a tour that includes visits to Greenlandic homes, where the host serves kaffemik while the local guide translates and tells the tourists about Greenlandic culture. The tours are organized by the local cruise tourism agency led by a local entrepreneur who would like to see the range of local products and involved townspeople expand even further:

Everyone looks forward to the summer, and I wish for this to be much more widespread. Because everyone always has a lot to offer. It can be different products, tastings in private homes of homemade products, and not just cakes and coffee, a bit different. (Entrepreneur)

A tourism student had been working with tourism development in a South Greenlandic town, a fishing town that is just starting to explore tourism possibilities. As she discussed tourism development in this town, she emphasized the need for cooperation and the inclusion of multiple local businesses, echoing the above views:

I had this feeling when I was in [that town] that they didn't think that tourism was a good fit for them; that it wasn't completely realistic. It didn't occur to them that there are other employment options in tourism. Because it's not just being a guide. 
It's about, in my opinion, being able to collaborate with different business owners at least in this town, because it's so small. (Student)

Of the four tourism students we interviewed, two would like to return to their respective hometowns to develop the tourism industry there. One of these two is focusing on how to include the other townspeople in tourism development, and the other wants to start her own tourism company building upon the local fishing industry. The two other students want to assist in building up the tourism industry anywhere in Greenland. We note that these students are partly motivated by working within and contributing to the local community while also wanting to contribute to the whole country. As one student said, "You can't do everything alone and you need to stand together to help and develop, and not just the individual town, but all the towns and society as a whole."

Economic development at the local community level is thus an important aspect in understanding entrepreneurship in Greenland, and entrepreneurs are reflexive about how their businesses can contribute to society by creating opportunities for the community.

\section{Cultural and personal pride}

According to the survey (Figure 3), the third most important source of motivation is 'create new products'. Interviews with entrepreneurs show that the product itself often seems to create both cultural and personal pride for many entrepreneurs. Tourism entrepreneurs often work to give tourists cultural insights. In the process, they often come to reflect upon landscapes and cultural aspects. One entrepreneur described how she used to doubt her own identity but realized the magnificence of Greenlandic culture and wants to share it with others:

When I started my own company, I promised myself that the tourists should learn five words in Greenlandic or they had to do the dishes. That makes them happy and they laugh a little. That's how it started, and I have wondered why Eric the Red and Leif the Lucky have taken so much from the history. So much that the Greenlandic version is drowning [...] I have heard many people say that Greenlanders don't do well. In anger, I once said to myself that I would never be a Greenlander [...] The words I once said only came out of anger, and I need to make amends by telling people about the seal. The seal made us survive in the cold. (Entrepreneur)

In this example, the business model of the Greenlandic entrepreneur is applied to reclaim personal and Inuit self-worth, drawing connections to Indigenous entrepreneurship in a postcolonial context. The special hybrid of personal-cultural pride is also visible among youths working in tourism as a young guide expresses the cultural pride and sense of belonging connected to his ability to steer tourists around local landscapes and communities: "I feel so at home when I work with tourists in [this region]. It's because I know [these towns] and everything that surrounds [them]." He continues:

When I'm guiding, I'm proud that I'm the one arranging things and showing them around town. I'm the one talking about Greenland's history and such. It's good for me to have that - to be able to tell what Greenland is. (Tour guide) 
Places, landscapes, history, and culture are obvious symbols of national identity, also for the entrepreneurs for whom culture is both part of their motivation and their business product. In their everyday activities, Greenlandic entrepreneurs engage in constructing and negotiating the meaning and content of Greenlandic culture through the narratives they communicate and the meals they serve.

\section{Family life and staying in a place}

According to the survey (Figure 3), the fourth most important source of motivation is 'pass on values to children'. The example of one young entrepreneur couple illustrates this. The couple moved back to South Greenland from Nuuk to take over the family sheep farm. It is not possible to run the farm based on the income from the farm alone, so the wife also has a full-time job, and they supplement with tourism activities offered at the farm during her summer holidays:

Being a sheep farmer probably isn't as good as it used to be. Perhaps just ten years ago, things were much better. Now we have the drought, where rain just doesn't come. But then we thought that we wanted to have something to do with tourism to make more money so that we didn't have to move from our farm. Particularly because it's a family farm, and we want to stay here, even though it doesn't give that much. But we want to be here. It's all about honor, family, and all that, you know? I don't know how to put it into words. (Entrepreneur)

The combination of several entrepreneurial activities makes it possible for the couple to stay on the farm. For them, the farm represents a certain way of life and positive values that they wish to pass on to their children:

[The tourism season] isn't a long period of time. But we're able to earn a good income so we can stay on the farm and make it work. Then we have the sheep in the winter and tourists in the summer. Then we can stay at home. Then we don't have to sell the farm or move elsewhere. And while you're there and doing all this, then you think about how we would actually also like to give our children the opportunity to grow up on a farm and work like we do. Because it has some sort of value that you can't measure in monetary form. You just can't. And you also know that not everyone has this opportunity. And it must be really cool to grow up like that. (Entrepreneur)

The values that entrepreneurs wish to pass on to their children are associated with place in different ways. This couple mentions the family farm, while the couple from an example mentioned above who moved back to Greenland emphasizes the Greenlandic language and culture, which most people lose if they do not remain in Greenland. The entrepreneurial way of working itself also represents values that can be passed down from parents to children by involving them in the activities. Many of the entrepreneurs who had experienced this themselves as children mentioned this: 
I think I got it from my father when I was little. I always had to help him planting potatoes, beets, and radishes. So, he taught me then: "Now you need to start planting radishes, they need this and that. And then when you have grown them, then you are ready to wash them-which I did — and then you are ready to sell them. Maybe for 5 kroner. That, you must think about in the future-what can you make and sell yourself?" It need not be radishes, but he taught me, that when you have made them, they're yours. So, when you sell them, it's your money [...] and when I was 12 years old, I started [a small business]. (Entrepreneur)

Entrepreneurship can thus be motivated by family relations. Entrepreneurs choose to work together with their children as a way of passing down motivations, values, and sometimes even language and places.

\section{Conclusion}

This study has explored entrepreneurship in Greenland and contributes to a contextual understanding of entrepreneurship, which emphasizes entrepreneurship as more than just an economic endeavor. Entrepreneurship instead consists of a combination of multiple, intertwined sources of motivation that traverse personal, local, and national scales. Much of the tourism entrepreneurship in Greenland is indeed motivated by the peripherality of the local community; builds upon Indigenous, place-based resources; and interacts with underlying discourses of Indigenous pride, revitalization, and independence.

We think a good term for this particular type of entrepreneurship could be 'Indigenous island entrepreneurship'. With further studies of entrepreneurship on islands with Indigenous populations, a more exact delineation of the term could be accomplished. Indigenous island entrepreneurship has three main characteristics:

- Indigenous island entrepreneurship is not primarily motivated by economic growth or income opportunity; rather, it is a means of maintaining personal autonomy and being able to continue living in a place.

- Indigenous island entrepreneurship is often narrated and practiced as a highly collaborative and distributed achievement. It is not centered around any one individual actor.

- Indigenous island entrepreneurship is about developing the community or communities with which one identifies, and it offers a tool for cultural empowerment.

The survey data and the interviews with Greenlandic tourism entrepreneurs in this article reveal multiple sources of motivation functioning simultaneously. We have shown how their activities interweave with an interest in personal autonomy, the desire to support and contribute to the local and national community, and an increasing sense of self-worth that comes from promoting Greenlandic culture, history, family, and place relations. On average, national independence as an isolated motivation ranks lower among Greenlandic entrepreneurs than these other motivations. But national independence is not irrelevant, neither to the population in general nor to half of the entrepreneurs who answered the survey. 
Replacing the block grant from Denmark-while also taking over more political areas of responsibility, consolidating the public finances, and raising living standards in Greenlandis an immense task. It is difficult to imagine the small-scale Indigenous island entrepreneurs creating enough jobs and growth in Greenlandic society to achieve all these economic development goals. From a narrow short-term perspective, the contribution to the economy of many Indigenous island entrepreneurs might have been bigger if they took a job in an existing organization or company. However, these entrepreneurs are possibly contributing to the creation of a self-sustaining economy by means of developing an entrepreneurial culture and laying the foundations for the future success of Greenlandic growth-oriented entrepreneurs.

We would argue that Indigenous island entrepreneurship also offers something unto itself. To appreciate this 'something', we must first broaden our discussions about sustainability. The Indigenous island entrepreneurship that has been sketched out in this article is developed in a culturally and socially meaningful way. It is currently designed by individual Indigenous entrepreneurs to meet their unique motivations in a specific social, cultural, geographical, and political context. From a long-term perspective, Indigenous island entrepreneurship might even offer a special route to economic and political independence that is inherently context sensitive, targeted at communities and personal-cultural wellbeing, and hence highly socially and culturally sustainable.

\section{References}

Agneman, G. (2019). Economic rationales for secession: The role of regional redistribution in moderating independence aspirations. SSRN. https://ssrn.com/abstract $=3409184$ or http://dx.doi.org/10.2139/ssrn.3409184

Baldacchino, G. (2015). Small island states and territories: Vulnerable, resilient, but also doggedly perseverant and cleverly opportunistic. In G. Baldacchino (ed.). Entrepreneurship in small island states and territories (pp. 1-28). New York \& London: Routledge. https://doi.org/10.4000/etudescaribeennes.6984

Bjørst, L. R., \& Ren, C. (2015). Steaming up or staying cool? Tourism development and Greenlandic futures in the light of climate change. Arctic Anthropology, 52(1), 91-101. https://doi.org/10.3368/aa.52.1.91

Burnett, K. A., \& Danson, M. (2017). Enterprise and entrepreneurship on islands and remote rural environments. The International Journal of Entrepreneurship and Innovation, 18(1), 2535. https://doi.org/10.1177/1465750316686237

Central Intelligence Agency (CIA) (2018). The world factbook. Retrieved from https://www.cia.gov/

Dana, L. P. (2007). A comparison of Indigenous and non-Indigenous enterprise in the Canadian sub-Arctic. International Journal of Business Performance Management, 9(3), 278286. https://doi.org/10.1504/ijbpm.2007.013308

Dana, L. P. (2015). Indigenous entrepreneurship: an emerging field of research. International Journal of Business and Globalisation, 14(2), 158-169.

Dana, L. P., \& Dana, T. E. (2005). Expanding the scope of methodologies used in entrepreneurship research. International Journal of Entrepreneurship \& Small Business, 2(1), 79-88. https://doi.org/10.1504/ijesb.2005.006071 
Departement for Finanser (2016). Vision og berende principper for Holdbarheds- og vakstplanen. Nuuk: Ministry of Finances and Mineral Resources.

Departement for Finanser (2018). Økonomisk Redegørelse 2018. Nuuk: Departement for Finanser.

Drews, C., Hart, M., \& Stephan, U. (2015). Understanding motivations for entrepreneurship: A review of recent research evidence. London: Enterprise Research Centre.

Flyvbjerg, B. (2001). Making social science matter: Why social inquiry fails and how it can succeed again. Cambridge: Cambridge University Press. https://doi.org/10.1017/cbo9780511810503

Gaddefors, J., \& Anderson, A. (2018). Context matters: Entrepreneurial energy in the revival of place. In D. Higgins, P. Jones, \& P. McGowan (eds.). Creating entrepreneurial space: Talking through multi-voices, reflections on emerging debates (pp. 63-78). Bingley: Emerald. https://doi.org/10.1108/s2040-72462018000009a004

Gallagher, B. M. (2015). Entrepreneurship and Indigenous identity: Three studies on the connections between Indigenous identity and entrepreneurial practices in Canada and Australia. Doctoral dissertation, Beedie School of Business Faculty: Segal Graduate School.

Greenland Business (2019). Ivarksatterundersogelse 2018. Published

online at: http://www.innovation.gl/media/83619/ivaerksaetterundersoegelse2018-dk.pdf

Grigore, A. M., Marinescu, P., \& Toma, S. G. (2014). Economic development and entrepreneurship. Procedia Economics and Finance, 8, 436-443. https://doi.org/10.1016/s2212-5671(14)00111-7

Grønlands Statistik (2019). Greenland in Figures 2019. Nuuk: Grønlands Statistik.

Gupta, A., \& Ferguson, J. (1997). Discipline and practice: 'The field' as site, method, and location in anthropology. Anthropological Locations, 100, 1-47.

Kahneman, D. (2011). Thinking, fast and slow. London: Penguin.

Labriandis, L. (2006). Fostering entrepreneurship as a means to overcome barriers to development of rural peripheral areas in Europe. European Planning Studies, 14(1), 3-8. https://doi.org/10.1080/09654310500339067

Mika, J. P., Warren, L., Foley, D., \& Palmer, F. R. (2017). Perspectives on Indigenous entrepreneurship, innovation and enterprise. Journal of Management \& Organization, 23(6), 767-773. https://doi.org/10.1017/jmo.2018.4

Pato, M. L., \& Teixerira, A. C. (2014). Twenty years of rural entrepreneurship: A bibliometric survey. Sociologia Ruralis, 56(1). https://doi.org/10.1111/soru.12058

Ren, C., \& Chimirri, D. (2017). Turismeudvikling i Grønland: Afdakning og inspiration. Department of Culture and Global Studies, Aalborg University. Aalborg.

Ren, C., \& Mahadevan, R. (2018). 'Bring the numbers and stories together': Valuing events. Annals of Tourism Research, 72, 75-84. https://doi.org/10.1016/j.annals.2018.06.008 Rosing, M., Knudsen, R., Heinrich, J., \& Rasmussen, L. (2014). To the benefit of Greenland. Nuuk \& Copenhagen: Ilisimatusarfik \& University of Copenhagen.

Rossen, R. (2018). Uluer, isbjørne \& Nuuk Posse - de grønlandske politikeres brug af symboler i moden og de unges modreaktion på det. Tidsskriftet Gronland, 66(2), 106-114.

Rossen, R. (2019). Young Greenlanders as influencers: Taking Nuuk City to the world. In Ilisimatusaat: Research projects at Ilisimatusarfik (pp. 6-7). 
Schumpeter, J. A. (1942). Capitalism, socialism and democracy ( $3^{\text {rd }}$ edn.). New York: Harper. Sejersen, F. (2007). Entrepreneurs in Greenland. In L. P Dana \& R. B. Anderson (eds.). International handbook of research on Indigenous entrepreneurship (pp. 201-210). Cheltenham: Edward Elgar. Sherifi, M. (2016, November 3). Join the Greenland beer revolution. An Adventurous World. Retrieved from https://www.anadventurousworld.com/greenland-beer Steenholdt, N. C., \& Chimirri, D. (2018). Tourism and quality of life in Greenland: Exploration through farm stays in South Greenlandic settlements. In L. Heininen, H. Exner-Pirot, \& J. Plouffe (eds.). Arctic yearbook (pp. 123-140). Akureyri: Northern Research Forum. https://doi.org/10.1017/s0032247418000256

Wennecke, C. (2017). Political-economic indicators for a self-sustainability in Greenland. The Northern Review, 45, 93-111. https://doi.org/10.22584/nr45.2017.006

Åstebro, T., Herz, H., Nanda, R., \& Weber, R. A. (2014). Seeking the roots of entrepreneurship: Insights from behavioral economics. Journal of Economic Perspectives, 28(3), 49-70. https://doi.org/10.1257/jep.28.3.49 